
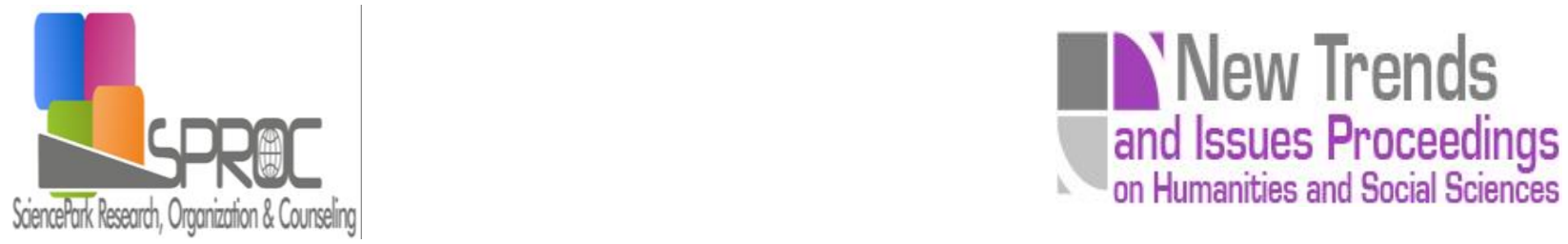

\title{
A morpho-semantic study of the diminutive suffix
}

\section{in Persian}

Ava Imani *

Gholamreza Kassaei

Suggested Citation:

Issues Proceedings on Humanities and Social Sciences.

Abstract 
1. Introduction

2. An overview of previous research on diminution 


\section{Theoretical framework}

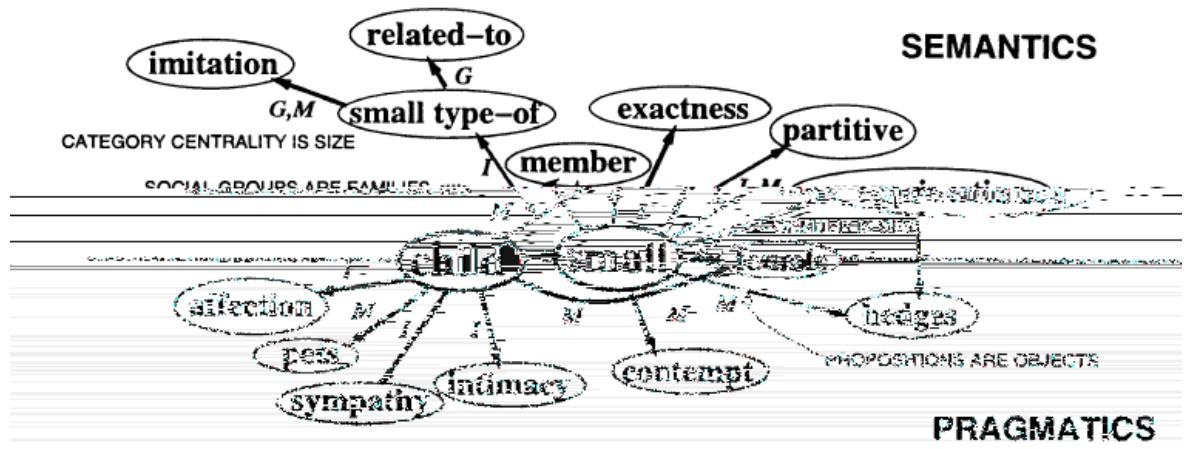

Figure 1. Proposed universal structure for the semantics of the diminutives 
4. Analysis of the data and discussion 
5. The semantic network for the suffix -æk in Persian 


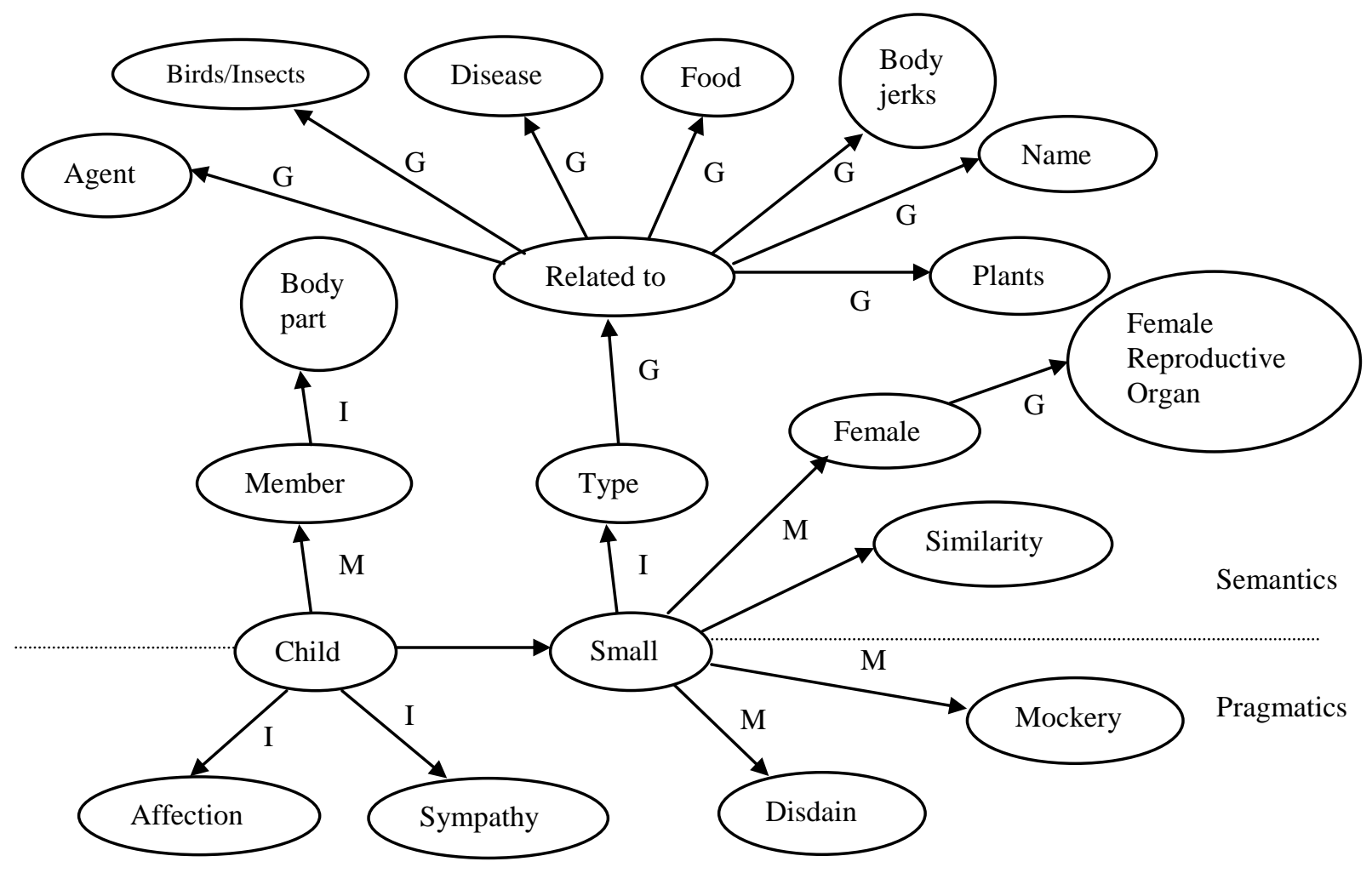

Figure 2. The proposed semantic network for the suffix -æk.

\section{Conclusion}




\section{References}

\section{Dastur-e zaban-e Farsi 2}

Dastur-e zaban-e Farsi-e no

in Polish Linguistics

Studies

\section{Loqatname Dehkhoda}

German and other languages

Morphopragmatics: Diminutive and Intensifiers in Italian,

).

Syntax and Semantics

Prace Filologiczne

Language

Sakht-e vazhe-ye eshteghaghi dar Farsi-e no

Zanan, atash, va chizha-ye khatarnak: tabaghe-ha dar mord-e zehn che neshan

midahand

Dastur-e Farsi-e moaser

$$
\text { Dastur-e zaban-e Farsi }
$$

Essays on Persian Language word formation

Dastur-e zaban-e Farsi (Panj Ostad)

Abzar-haye sakht-e vazhe dar Farsi-e moaser (2)

Dastur-e jame-e pishvand-ha va pasvand-ha-ye Farsi

Dastur-e zaban-e Farsi

Balkanistica 
Linguistics Categorization: Prototypes in Linguistics Theory

\author{
Approaches to grammaticalization
}

. $\ln$

" Quaderni di Semantica

Persian grammar in morphology and syntax of orthography in Persian 